\title{
Re-Envisioning the Sites and Sights of the Late Twentieth Century Study of Religion
}

In the course of the 1997 spring semester, I undertook something of a globalizing sabbatical visiting Britain, Finland, Germany, South Africa, Senegal, Denmark, Ghana and Nigeria. I enjoyed and benefited from a whole range of stimulating insights from colleagues and students in the various places that I visited. I was made acutely aware of how different are the conditions in which our colleagues work in various parts of the world. While some enjoy enviable research support, others, such as in West Africa, cope valiantly with political, economic, structural and cultural adversities-let alone the growing information gap. At times, our method and theory debates look like a luxury in our comfortable, relatively unthreatened, and privileged (mainly Western) academic worlds.

That notwithstanding, this paper affords me a welcome opportunity to share some of the findings and observations from my itinerations. Its substance, therefore, would be better characterized as fragmented and eclectic, and exhortatory rather than technical. It also would be rightly termed an "aerial view". The gist is that the academic study of religion must now encompass more than it has done until now the effects of modern media and communications technologies, global consumption patterns, cultural mobility, and changing geo-political configurations. Religious actors and organizations are more than ever key players on the world stage. I am concerned that as scholars of religion we are being outpaced by these developments, whether because of the limitations of our vision, or the shortsightedness of our theoretical lenses. ${ }^{1}$ I intend to argue, without the luxury of elaboration-since I have opted for breadth of scope rather than depth of

\footnotetext{
${ }^{1}$ Sociologists of religion do not seem to lag behind so much--the 1997 Society for the Scientific Study of Religion meeting in San Diego comprised panels on cyberspace and religion, Generation $\mathrm{X}$ and spirituality, globalization, press coverage of religion, religion in the media age, religion as popular and cultural practice, to name a few.
} 
argument-that sites such as art, the media, Internet, outer space, diasporas, global culture, nature, and the public space deserve our critical attention-not just for reasons of content, but because these new or neglected sites offer a potential challenge to our categories and concepts. We have to shift our focus increasingly from bounded local cultures to transnational cultural flows and reexamine the significance of place (or non-place, see Augé 1995). We need to be part of the globalization debate, building on the excellent work of Roland Robertson (e.g. 1989) and Peter Beyer (1998; 1994) who have sought to emphasize the role of culture, and more specifically, religion, in worldwide social and cultural change. In this way the most interesting problems (which used to be ours according to Ninian Smart) are not monopolized or pinched from under our noses by our colleagues in cognate areas.

Furthermore, as a committed scholar of religion, who moves in a number of academic circles-notably African studies, anthropology, art history, cultural studies, and human rights-I continue to be dismayed at the way in which our scholarship is all too often ignored, underestimated or misunderstood. ${ }^{2}$ That in part stems from the complex, controversial and challenging subject matter we treat (and non-specialists' fear of it), but also due to our own reluctance to alter our focus or tardiness in engaging current theoretical debates. I claim limited knowledge of the apparently fertile field of religion and cognitive science but am happy to say that this is obviously one subgroup of scholars who have put religious studies and religion on the scholarly map. ${ }^{3}$

Before I move on, let me just cite the case of cultural studies to illustrate what I mean about missed opportunities and being missed out. Religion is conspicuously absent from their academic slate. For example, in a recent publication on Questions of Cultural Identity, edited by Stuart Hall and Paul du Gay (1996) there is not a single entry on religion. The same can be said of Ioan Davies' Cultural Studies and Beyond: Fragments of Empire (1995). This could of

\footnotetext{
${ }^{2}$ An example of this would be the launching of the American Anthropological Association's Anthropology of Religion group in November 1996 in San Francisco where references to "comparative religion" were outdated--overly emphasizing the metanarratives of earlier scholarship.

${ }^{3}$ See, for example, the special issue of Method and Theory in the Study of Religion on "Cognition, Culture, and the Study of Religion," vol. 8/2 1996. The journal as a whole has rapidly established itself as the primary site of stimulating methodological and theoretical discussion in the academic study of religion.
} 
course be attributed to the Marxist leanings of earlier (British) scholars in the field who viewed religion as "residual" and as a "weak and waning presence" (Murdock 1997: 89), but it is also our responsibility for not engaging them in dialogue. There are efforts to counteract the inattention to religious issues. A recently produced book, edited by Hopkins and Davaney, Changing Conversations: Religious Reflection \& Cultural Analysis and (1996) seeks to promote religion (although their lens is predominantly theological) as an integral component of cultural studies. I am also happy to note that one of my own colleagues in Religious Studies at the University of Tennessee, Knoxville, Mark Hulsether, who comes out of the American Studies/cultural studies tradition has cogently argued in his piece, "Three Challenges for the Field of American Studies: Relating to Cultural Studies, Addressing Wider Publics, and Coming to Terms with Religions" (1997) that religion does not deserve its omission from their scholarly ambit. There is also a new series, entitled "Zones of Religion" (edited by Peter van der Veer for Routledge) which links religion, anthropology and cultural studies.

\section{Art: Seeing Is Believing}

Of the various sites and sights I have chosen to discuss in this paper, I am beginning with an obvious one-obvious because it has become something of a cause célèbre for me in recent years. Furthermore, it usually generates interest and support rather than controversy. I am here talking about art. Since I became involved in the writing of my recent book on Art and Religion in Africa (1996a) for the series Religion and the Arts, I have become an advocate for a more central role for the visual and performing arts in our scholarly enterprise. I have also shown in a couple of other publications how art may provide a window onto religious change (1996b), as well as gender relations (1998b). I firmly believe that a focus on art can bring a fresh perspective to our studies, notably by challenging the hegemony of the written text in our academic discourse. I am also interested in the reasons for the marginalization or even outright neglect of the visual in the history of religions. ${ }^{4}$ For instance, I have argued that the privileging of word over image in Western culture and the Protestant

\footnotetext{
${ }^{4}$ Similar "blind spots" are also encountered in anthropology. Cf. the edited work by Coote and Shelton (1992) which seeks to counteract the marginalization of art within anthropology.
} 
fear of or trivializing of the visual are undeniable influences in this regard (1996a: 15).

I am not alone in this crusade. Doug Adams and Diane ApostolosCappadona, in the introduction to their book, Art as Religious Studies, rightly state that the "discipline of seeing" has been absent from the scholar of religion's tools of the trade (1987: 9). Of course one can point to scholars, notably those active in the American Academy of Religion's Arts, Literature, and Religion section, who have been concerned with the connections between religion and art. Space precludes an overview of the field, but a few brief remarks are apposite here. A new journal was launched by Boston College in 1996 entitled Religion and the Arts. Casting its net wider than the visual arts, it claims that " $[t]$ he expression of religious sentiments in art is a deeply significant feature of all manifestations of religious belief and a foundational aspect of all cultures" and that it has been set up as a "timely response to a widespread new acceptance of the value of interdisciplinary appreciation of artistic religious expression for the understanding of religion as well as art itself."

Individual scholars, such as Diane Apostolos-Cappadona, have been active in publishing a number of relevant works and arguing for art to be viewed as a primary source in the study of religion (e.g., 1998, 1996, 1995, 1994, 1986). Apostolos-Cappadona has tended to limit her perspective to the Jewish and Christian traditions, however. This has been the case with some other scholars also who have focused on Christian art and in particular its theological and liturgical importance (see, for example, Dillenberger 1965). The American journal, Image: A Journal of the Arts and Religion (launched in 1994) also embodies the pragmatic, spiritual perspective. What a pity that the recently published Oxford Dictionary of Christian Art and Architecture limits itself to the Western world-thereby missing out on all the exciting manifestations of African Christian art and architecture over the last few decades (this was considered important enough by the way to make the front page of Time magazine some years ago!) (for the Pacific, see Moore 1995).

Ninian Smart added at a later stage (1989; 1996) the "material" dimension (in which he included art works) to his well-known sixdimensional framework of religious traditions (1983) (note: he does however place it last). The scholar of indigenous religions, Sam Gill, has a chapter in his book, Beyond "The Primitive", on "Beauty and the Drainpipe: Art and Symbolism in Religion" (1982: 28-37). He argues, quite rightly, that oral cultures challenge us to look at the phenomenon of religion in a more nuanced and multi-dimensional way. When in South Africa in January 1997 I was happy to obtain a copy 
of Kobus Krüger's (1995) book entitled Along Edges: Religion in South Africa, Bushman, Christian, Buddhist. He is attentive to the role of symbol in general in religion-but is interested more specifically in exploring the abstract symbolism of "Bushman" engraving art, some of which dates back 25,000 years.

Turning to the Scandinavian scene, Tore Ahlbäck's Dance, Music, Art and Religion (1996), resulting from a Donner Institute symposium in 1994, contains a tantalizing collection of essays on topics ranging from old Norse music, and contemporary Coptic images, to Madonna videos and the iconographic aspects of UFO mythology. Professor Jan Bergman's $65^{\text {th }}$ birthday in 1998 elicited a fine collection of texts on religious iconography and iconology (Schalk 1998). These tend to be exceptions, as alluded to by Håkan Rydving, in his study of religious change among the Lule Saami (1993: 31). He observes that historians of religion have made little use of the sacrificial sites and their ritual remains for the study of Saami religion. He also cites the archaeologist and ethnographer, O. Vorren, who comments that such scholars (i.e. historians of religion) have found the written sources more attractive than an analysis of the artefacts of sacred sites.

Mircea Eliade, to his credit, always had an eye for the religious significance of artistic form (see Apostolos-Cappadona 1986; Eliade 1961). In addition to his passion for the Romanian sculptor, Brancusi, he also wrote about other traditions ranging from Eskimo to Hindu. Philosophers of religion have occasionally turned their hand to analyzing the relationship between religion and art, drawn by questions of aesthetics and the conflict within some religious traditions over representing the divine (e.g. Raschke, Kirk and Taylor 1977; Laeuchli 1980). Mark C. Taylor's impressive Disfiguring: Art, Architecture, Religion (1992) is an analysis and (re)construction of the interplay between religion and the visual arts. In his own words,

... a thoughtful exploration of some of the most provocative art of our time opens an alternative space for the a/theological imagination. ... It would not be inaccurate to understand this venture as an effort to rethink the interrelation of Kierkegaard's three spheres of existence: the aesthetic, the ethical, and the religious (1992: 5-6).

Greg Alles, in his insightful and trenchant review of Taylor's work (1996), criticizes him for suggesting that among twentieth-century theologians Tillich was the only one to show interest in modern art, and for failing to give credit to the considerable efforts of the aforementioned Arts, Literature, and Religion section of the American 
Academy of Religion. One would also want to give credit to Larry Sullivan for organizing a number of seminars at the Harvard University Center for the Study of World Religions on the religious arts (see fall 1996 bulletin). The recently published, Critical Terms for Religious Studies (1998), contains an entry by Margaret Miles on "Image."

I want to mention two aspects of my own work that I believe merit wider scholarly discussion. I have always argued that the concept of power is central to much of what outsiders and insiders might term "religion" (e.g. Hackett 1993). I am further arguing here that a focus on the arts is conducive to a more nuanced and polythetic understanding of the perceived sources and relations of power of the human and spirit worlds. It may in some circumstances force us to recast our perceptions of where "power" is located in a particular ritual setting, for example. It is not necessarily the largest, most colorful, most central or public masquerade that may be held to be the most powerful (as uninformed Western observers are prone to surmise). The most highly charged masks may be hidden away in the shrines, the most significant character may be the old woman chanting on the edge of the circle. The Nigerian art historian, Rowland Abiodun, has shown most convincingly in his work how the complex Yoruba philosophical concept of asse ("the power to make things happen") can only be understood through a careful examination of the verbal and visual arts (1994).

Second, my incursions into the realm of the visual revealed one problematic and challenging area in particular, that of representation. This is discussed in chapter two, "Envisioning and (Re)Presenting the Spirit World," of my book (1996a). The complexity of the perceived relationship between spirit forces and art objects is often glossed over by the too ready use of terms such as "representation." This term in particular elides or disguises the ways in which an art object may range from being associated with supernatural power to being an actual image or manifestation of that power. The work of several scholars has illuminated the dynamics of these processes of embodiment and (re)presentation. The whole area of masking is particularly apposite here. The ambiguity of the masking process and the notions of personhood it raises have been helpfully treated by the philosopher and anthropologist, David Napier (1986). A recent special issue of African Arts (31/2: 1998) on "Women's Masquerades in Africa and the Diaspora" offers a wonderfully rich and challenging set of essays on the performance and agency of women in relation to masking. Overall this would seem to be an area where scholars of religion could contribute much to the analysis and discussion. 


\section{Media}

There is so much more to be said about art and the study of religion, but I would like to turn now to a somewhat related area, in that it may also involve the visual-that is the electronic and print media. One scholar alleges that the "mediaization of modern culture is more important than the alleged secularization and rationalization of social life" (Thompson 1990: 265). ${ }^{5}$ The media have undeniably become a key site for the representation and invention of religious ideas and praxis. African traditional religions illustrate this well. One only has to recall such feature films as Angel Heart, The Believers, or Dr. No, or popular series like the X-files and Miami Vice, for example, to conjure up (pun intended) a very negative and fearful image of African-derived religions, with "voodoo" at the top of the list. Vodun practitioners do not stick pins in dolls. This is an invention of Hollywood or Hoodoo boutiques in New Orleans. More enlightened sources are available for examining the place of material objects in African religions, such as art historian, Suzanne Preston Blier's African Vodun: Art, Psychology and Power (1995), the French anthropologist, Marc Augé's Le Dieu objet (1988), and William Pietz's series of penetrating articles on the concept of the "fetish" (1988; 1987; 1985).

Turning to mediated sources within Africa itself, I would like to draw attention to the role of African governments (but let's not exclude here such foreign agencies as the British Council, the Goethe Institut and the Alliance Française) in promoting a "sanitized" and "safe" image of African religions as "spectacle" through staged festivals and performances. We should not forget either the role that academic texts, which are quite capable of taking on a life of their own in the wider marketplace, may also nurture popular images of a people's traditional religious heritage (see Shaw 1990). The construct of "ATR" (African Traditional Religion) is apposite here. A rapidly growing sector responsible for inventing tradition is the whole area of Christian inspirational literature and tapes. In particular, I am referring to the indigenous local production of the pentecostal and charismatic movements which have become so popular and influen-

\footnotetext{
${ }^{5}$ An international workshop on "Religion and Media" was organized in Paris in December 1997 by the Amsterdam School for Cultural Analysis in cooperation with UCLA's Paris Program in Critical Theory and the Institut Néerlandais. We look forward to their publication from Stanford University Press. A more focused project, whose results are also eagerly awaited, is the joint project on Yoruba Religious Publics of the School of Oriental and African Studies and the Centre for West African Studies in the U.K.
} 
tial over the last two decades in many parts of Africa (see Hackett 1998a). These groups are founded on the dualistic theodicy and moral strictures of evangelicalism, and centered on the workings of the Holy Spirit. They specialize in generating demonic images of "traditional" religious beliefs and practices, whether it be to do with ancestors, witches, healing or libations (cf. Meyer 1992). Women fare poorly in all of this, being viewed as especially vulnerable to the wrong type of spirit possession, namely by troublesome and demanding water spirits (known more widely as Mamy Wata) (see Hackett 1996a: 147-149, 194-195). All of these mediated discourses are significant since they can enjoy wide circulation via government television and publications, or commercial and religious outlets. Regrettably (at least in my opinion), traditional religious specialists are either reluctant to, unable to, or prevented from, representing themselves via the modern media.

Keeping on the theme of the invention of religious traditions and circulatory flows of religious images and ideas, I should like to say more about how Christianity and Islam fare in the African context. Amazingly, virtually no studies of the relationship between religion and the media exist, despite the fact that many African countries have long supported religious programming of various types. This may include BBC-type mainline Christian Sunday services, the now hugely popular charismatic preachers and gospel music groups, Muslim sermons and talks-especially at Ramadan, as well as discussion programs on metaphysical questions, often including the functionaries of spiritual science groups such as the Rosicrucians. While access to airtime may be determined by government or financial considerations, it is not hard to argue that the media constitute an important new site for religious groups to generate images of self and other, and to compete for public space. So why, I ask my African colleagues, are they neglecting this area of potentially rich research, or why, for example, do my sociologist friends in Europe and the U.S. remain so parochial when they churn out their studies on televangelism? However, I am pleased to see the publication by anthropologists Babb and Wadley on the media and religious transformation in South Asia (1995). Some of the articles in a 1997 special issue of Africa on "Audiences in Africa" (guest edited by Karin Barber) tackle religion-see, for example, Launay 1997. I am here trying to underline the potential of religious broadcasting and popular, inspirational literature as areas for studying the creative interplay of local and global religious forces, whether the protagonists be Cerrullo, Idahosa, Bonnke, Gumi, Deedat or Farrakhan. More research, from diverse cultures, is required. Perhaps it requires transcending the view that 
the media are trivial sources of knowledge-and rather perceiving them as a rapidly changing and challenging field of study with profound implications for concepts of religious community, spiritual power and its circulation, and relations between religion and the state (cf. Hoover and Lundby 1997; Hackett 1998a).

\section{New Age/Old Hat?}

Towards the end of the American Academy of Religion's annual conference in San Francisco some years back (1992), I remarked to Ninian Smart on the absence of panels or papers on New Age religion, an obvious topic for California. He heartily agreed with me. The situation has somewhat improved with California-based scholars such as Gordon Melton and James Lewis producing a number of useful texts on the subject (e.g. Lewis and Melton 1992). Some Danish, Dutch, British and German colleagues have lent credence to this subfield through their publications and research activity (see e.g. Heelas 1996, Bochinger 1995, Hanegraaff 1996). Steve Bruce has devoted a whole chapter on the New Age in his recent book on Religion in the Modern World (1996), and articles on the subject now appear fairly regularly in the Journal of Contemporary Religion (e.g. the January 1998 issue, vol. 13: 1). But there remains an ongoing discrepancy between the popularity and pervasiveness of this very eclectic and creative religious activity and scholarly attention. In some cases, younger colleagues (particularly if they operate within theology faculties) face stigma and discrimination should they choose this as their main academic focus. I attribute this to a reluctance on the part of more established scholars of religion to engage popular culture forms more generally, and face the more commodified and transient manifestations of religion. ${ }^{6}$

I am gratified to note on my travels that some bolder students and younger scholars, such as in Finland, are keen to take on New Age religious beliefs and practices. They have realized, at very least, that the latter challenge some of our conventional definitions of religion, our patriarchal categories, as well as our methods and sites of inquiry. The locus of investigation shifts from clearly defined religious figures and texts to popular, inspirational literature, music, healing

${ }^{6}$ Cathrine Albanese informed me that a number of graduate students in the Department of Religious Studies are now pursuing topics in contemporary religion, including the New Age, at the University of California, Santa Barbara. Personal communication, April 26, 1998. 
and "experience-altering" techniques, "ethnic" artifacts, virtual gurus and outer space. Now I know Joseph Campbell's scholarly attributes have given cause for concern, but he must be given credit for recognizing the location of modern mythology in films such as Star Wars (Campbell 1988). With regard to New Age eclecticism, I myself find it a fascinating and useful academic exercise to explore with my students in the United States which aspects indigenous peoples select from their "religious" lives as part of the process of self-representation for the tourist market, or which artifacts and rituals get appropriated, revalorized and eventually commodified by outsiders.

\section{Cyber-Spirituality}

Most readers of this piece are probably avid Internet users, and some I know have constructed their own web sites, but how many have done fieldwork on the Net? Who has decided to investigate the myriad forms of religious activity in cyberspace? I first became aware of the ritual possibilities of the medium when an undergraduate student in my anthropology class some years ago wrote his research project on "Technopaganism" (I should add that he was a practising pagan and a computer science major!). Then another student, majoring in Religious Studies and Physics did a longer research project on "Cyberspirituality" as he called it; he focused on a very eclectic ritual group by the name of Techspirit- $\mathrm{L}$ whose members were exploring together different spiritual paths (Klasnja 1995). It was a fascinating project and it opened our eyes to the possibilities of this medium for reshaping the religious landscape and redefining the notion of religious community. It also raises the question of how local and global forces intersect and interact. While the Internet appealed primarily to persecuted or underground groups such as neo-pagans, it is now exploited by virtually all religious organizations. ${ }^{7}$ The Muslim Student Association in the U.S., for example, has used it very successfully to strengthen their network. Many of you may remember Heaven's Gate, with its sacralized view of electronic communication, and the shock waves sent through the world by the extremist actions of such a group.

\footnotetext{
${ }^{7}$ A national survey of teenagers shows that many teens in the US will eventually use the Internet for their only religious experience:

$<$ http://www.barna.org/PressCyberChurch.htm>.
} 
Why therefore are we not being serenaded by a host of scholarly analyses of this medium of communication? (One welcome exception is the work of Stephen O'Leary (1996) and O'Leary and Brasher (1996)). Two answers spring to mind: first, the sheer volume of Internet material is intimidating. One of my students for a project on shamanism/neo-shamanism eight years ago came up with more than 7000 sites! How many might there be now? Second, we do not have the tools to decipher and evaluate these new sites or "texts". Are they oral, written, visual, or performative, or a combination of all of the above? O'Leary, in his groundbreaking article on "Cyberspace as Sacred Space" (1996: 787 ff.), introduces a historical dimension to this revolutionary transition to the digital age by comparing it to the social and cultural revolution effected by the Reformation when Luther and his printing press were able to break the monopoly of the Roman Catholic Church on scriptural interpretation. Let us turn the trickle of scholarly articles into a flow of ideas on this important and fascinating new field of research (see also O'Leary and Brasher 1996), and not leave it all for the sociologists and popular culture specialists.

\section{Diaspora}

Thinking about the Internet leads into another topic I wish to discuss briefly because of its importance for scholars today and that is the concept of "diaspora". In his book on "Global Diasporas", (1997) Robin Cohen discusses the changing meanings of the term from the original Greek meaning of dispersal through colonization to now imply a positive and ongoing relationship between migrants' homelands and their places of work and settlement. By the year 2000 he claims there will be ten times the number of nation-peoples (2000) than nationstates (200). Yet the religious component of this important phenomenon is insufficiently studied and remains secondary to "ethnicity"-as Martin Baumann claims in his article on "Conceptualizing Diaspora" (1995; see also 1997). Cohen argues that "religions can provide additional cement to bind a diasporic consciousness, but they do not constitute diasporas in and of themselves" (1997: 189) (a cursory reading of the U.S. produced Hindu magazine, Hinduism Today, might challenge this notion). Ninian Smart, in a 1987 piece, maintained that with increased globalization even small religious communities can maintain contact with their epicentres (whether through pilgrimage, or one would have to add now the Internet), and take on the aspect of "global" religions. 
I do not intend to argue for or against the notion of a "religious diaspora" but I do want to suggest that the "cultural hybridization" and "creolization" of post-colonial times and spaces are crying out for our critical lenses. Some scholars have already noted the richness, in terms of religious creativity, of these "contact zones" (see, for example, Carrasco 1995; Carrasco 1996). ${ }^{8}$ Renato Rosaldo refers to these "border crossings" as important "sites of creative cultural production" (Rosaldo 1989: 208). I do not wish to belittle the fine work done by such scholars as Kim Knott (1994), Malory Nye (1996) and Steve Vertovec (1993) on Asian communities in Britain, for example, but "hybridity" as a category in the study of religion and the attendant issues of cultural translation, cultural hybridity, critical religious self-reflexivity and the moral battleground of identity, deserve further investigation in my opinion (cf. Werbner and Modood 1997; Hannerz 1996; Stewart and Shaw 1994).

I consider that the question of diaspora has to be discussed more within a global context, or global processes, i.e. the rapid developments in communications technology, transport and information which bring the remotest parts of the world within easy reach (cf. Giddens in Ahmed and Donnan 1994: 1) The authors of Islam, Globalization, and Postmodernity (1994: 4-7) refer to the "elasticity of the diasporic tie" and the "reciprocal redefinition of identity at both ends of the migratory chain." This is obviously heightened by the use of the Internet. How is religion, or the concept of the sacred for that matter, affected by its detachment from territory when it can have virtual and imagined contact with that territory? (cf. Anttonen 1996 for a more contextualized view of the sacred).

Two North American examples come to mind while still on the subject of diaspora. A much heralded CD ROM by Diana Eck entitled "On Common Ground: World Religions in the U.S." (Columbia University Press, 1997; see also Eck 1996) is now on the market. No doubt many world religions teachers will avail themselves of this attractive, multi-media production. But is there not a risk that students will concentrate on the U.S. versions of Buddhism, Hinduism, Islam, etc. with possible disregard for their earlier manifestations? In other words, the diasporic site might assume greater importance than the site of original development. Since the project is ongoing and there is no data available yet on use of the material, this remains a preliminary reflection.

\footnotetext{
${ }^{8}$ Actually Carrasco takes the concept from Pratt 1992.
} 
Karen McCarthy Brown's widely appreciated and hotly debated book, Mama Lola (1991) deals with the question of diapora in a more synergistic way. It is an account of her fourteen year relationship with a Haitian voodoo priestess in Brooklyn, New York. It describes and analyzes the diasporic Haitian community in New York and how their religion helps them survive in difficult conditions, and keeps them in touch with their homeland. In fact, Brown does this in a very creative way, by interspersing the factual narrative chapters on New York, with more fictional chapters on Mama Lola's Haitian ancestors. This book is important not just because of the content but also because of the writing style. It is a style influenced by the feminist leanings of the author, i.e. it is a type of subjectivist or experiential ethnography, and is underpinned by her concern to promote a more "honest" relationship between scholar and subject. She also conveys clearly and forcefully how religion is central to the life of a diasporic community, such as the one she describes in Brooklyn, New York, not just for reasons of cultural identity, but as a very strategy for survival.

Much of my research on new religious movements in Africa whether on Zionist churches in South Africa or pentecostal/charismatic movements in Nigeria over the years has convinced me that identity has been over-emphasized by many scholars at the expense of survival as an interpretation of religious movements, and their growth and appeal, etc. This leads into issues of religion and development, another neglected, yet potentially rich, area. Some Scandinavian colleagues (Dorthe von Bulow and Eva Evers Rosander) organized a very successful conference on this very topic in April 1997 in Copenhagen. Once again, it was quite obvious that scholars of religion had much to offer both in terms of their conceptual skills (notably in toning down excessive generalizations about "religion"), their fieldwork data and comparativist perspective.

\section{Globalization}

This is far too vast a subject to treat with any justice here, but I do want to reiterate my firm conviction that scholars of religion have much more to contribute to this debate than they have up to the present time. We glibly teach courses on "world religions", aided and abetted by the latest in glossy "world religions" textbooks, without seeing the "world" as a changing and constructed notion, not least due to the accelerated pace and complexity of exchanges facilitated by new technologies (Appadurai 1990: 6). Beyer (1998; 1994) and 
Robertson (1989), as referred to earlier, have been instrumental in moving the discussion on globalization away from solely economic or political issues to the cultural and religious. Robertson's work is helpful in understanding the dynamics of the globalization processnamely the intersection, the interconnectedness, and the interplay between global and local/individual forces. He also emphasizes the universalization of particularisms and the particularization of universalisms, embedded in the concept of "glocalization". Religious ideas, symbols, figures, and institutions are intimately tied to these developments. We need, for example, to examine how the former might promote greater homogeneity or heterogeneity or both in terms of global cultural patterns. New Age-type religious practices would illustrate this type of dialectic well. So too would evangelical and pentecostal forms of Christianity, as they foster local agency while promoting global, homogenized literary, homiletical, and musical forms through their freely circulating audio-visual productions.

\section{The Scholar of Religion as Public Scholar}

I want to say something in closing about the increasing discussion surrounding the scholar of religion as "public scholar." Some of you may say that this has little to do with the business of studying religion academically, but I say it does-especially if one expands the notion of methodology to how or where one operates as a scholar of religion. Our Danish colleagues, Tim Jensen and Mikael Rothstein, also think it does for they are planning an edited volume (in part) on the topic (see also Jensen 1998). Given my own place in some of these discussions, I want to offer some conjecture on the subject. I consider there to be at least two reasons why we find ourselves as scholars of religion in our respective contexts being called upon increasingly to offer our expertise in a public way.

First, religious activity is more evident than ever on the world stage and it is not just specialists of "sects and cults" who are sought after for sound-bytes. Articles on religion in U.S., newspapers are on the increase (cf. Silk 1995), for example, and a new public television series, entitled "Religion and Ethics Newsweekly" was launched in the fall of 1997.

\footnotetext{
${ }^{9}$ I take the term from Martin Marty. See especially the Symposium "Martin Marty, The One and the Many" in The CSSR Bulletin 27,2 (April 1998). This comprises a series of excellent critical pieces by scholars of religion responding to Marty's new book (1997).
} 
Second, I believe that there are only a few "ivory towers" left in the world where scholars of religion can function without defending themselves to the wider world and justifying their existence. This defense has become increasingly necessary for academic, political and/or budgetary reasons. For the last year I have belonged to the Committee on the Public Understanding of Religion within the American Academy of Religion which seeks to help scholars or religion understand better the "public sphere" and develop a more "professional" attitude to inquiring experts or members of the general public. In this regard, the former journalist, Mark Silk-also a member of the above committee, produced a very useful guide entitled, "A Religion Scholar's Guide to Dealing with the News Media" (for American Academy of Religion members). ${ }^{10}$

The pressures on scholars of religion to play a public and more pragmatic role in society are acutely felt in some parts of Africa, for example, where they are expected to play their part in national reconstruction. South Africa immediately comes to mind here, together with the book "Religion and the Reconstruction of Civil Society" edited by John de Gruchy and S. Martin (1995). Concerns about oppression and the need for scholarly criticism feed back into methodological and theoretical considerations-witness Martin Prozesky's important piece, "Proposals for a Criteriology of Religion" (1992; see also 1996). In many countries, religious pluralization and attendant religious intolerance and conflict have obliged scholars of religion to address these issues. Nigeria is a case in point, and one only has to look to the efforts of the Nigerian Association for the Study of Religions, which resulted in the publication of a lengthy volume, entitled Studies in Religious Understanding in Nigeria (Abubakre 1993) or Jacob Olupona's Religion and Peace in a Multi-Faith Nigeria (1992). My Nigerian colleagues have spoken to me over the years about their sense of obligation, sometimes pressure, to write on the contribution of religion to national development, especially in the area of values, as well as its role in the controversial issue of cultural unity/pluralism (see Olupona 1996; also Hinga 1996 on Kenya).

As an international organization, the International Association for History of Religions, and its members, seek to be supportive of and proactive with regard to their colleagues in those parts of the world where they do not have the same access to academic resources, funding, or interaction. This should be done not just for altruistic reasons but out of a genuine concern to expand the conversation

${ }^{10}$ See the website for the new organization he has founded, the Center for the Study of Religion in Public Life <http://www.trincoll.edu/ csrpl/>. 
among scholars, and to receive the insights and challenges of those coming from different cultural standpoints. There seems every hope that the upcoming XVIIIth Quinquennial IAHR Congress in Durban in the year 2000 will provide this type of forum.

This paper has suggested a number of pathways that are deserving of more exploration by scholars of religion. In sum, I argue that what we choose to include or exclude from our gaze affects the nature of our discourse(s) through and through. The whole business of "seeing" is integral to both the academic enterprise as well as the political economy of the academic study of religion. I have merely tried to highlight some of the exciting new areas that face us as students of religious ideas and phenomena, and point to their methodological implications.

\section{References}

\section{Abiodun, Rowland}

1994 Ase: Verbalizing and Visualizing Creative Power through Art. Journal of Religion in Africa 24: 294-322.

Abubakre, R. D. (ed.)

1993 Studies in Religious Understanding in Nigeria. Ilorin: Nigerian Association for the Study of Religions.

Adams, Doug, and Diane Apostolos-Cappadona (eds.)

1987 Art as Religious Studies. New York: Crossroad.

Ahmed, Akbar S., and Hastings Donnan (eds.)

1994 Islam, Globalization, and Postmodernity. London: Routledge.

Ahlbäck, Tore (ed.)

1996 Dance, Music, Art, and Religion. Åbo: The Donner Institute for Research in Religious and Cultural History. (Scripta Instituti Donneriani Aboensis, 16)

Alles, Gregory D.

1996 Review of Mark C. Taylor (1992): Disfiguring: Art, Architecture, Religion. Chicago: Chicago University Press. Journal of the American Academy of Religion 64: 174-78.

\section{Anttonen, Veikko}

1996 Rethinking the Sacred: The Notions of 'Human Body' and 'Territory' in Conceptualizing Religion. In: Thomas A. Idionpulos and Edward A. Yonan (eds), The Sacred and Its Scholars: Comparative Methodologies for the Study of Primary Religious Data; pp. 36-64. Leiden: E. J. Brill. (Studies in the History of Religions, 73)

\section{Apostolos-Cappadona, Diane}

1994 Dictionary of Christian Art. New York: Continuum.

1995 Art, Creativity, and the Sacred: An Anthology in Religion and Art. New York: Continuum. 
1996 Encyclopedia of Women in Religious Art. New York: Continuum.

1998 Dictionary of Women in Religious Art. New York: Oxford University Press.

Apostolos-Cappadona, Diane (ed.)

1986 Symbolism, the Saved, and the Arts/ Mircea Eliade. New York: Crossroad

Appadurai, Arjun

1996 Modernity at Large: Cultural Dimensions of Globalization. Minneapolis: University of Minnesota Press. (Public Worlds, 1)

Augé, Marc

1988 Le Dieu objet. Paris: Flammarion.

1995 Non-Places: Introduction to an Anthropology of Supermodernity. London: Verso.

Babb, Lawrence A., and Susan S. Wadley (eds.)

1995 Media and the Transformation of Religion in South Asia. Philadelphia: University of Pennsylvania Press.

\section{Baumann, Martin}

1995 Conceptualizing Diaspora: the Preservation of Religious Identity in Foreign Parts, Exemplified by Hindu Communities Outside India. Temenos 31: 19-35.

1997 Review of Robin Cohen: Global Diasporas: An Introduction. London: UCL Press. New Community 23: 572.

\section{Beyer, Peter}

1994 Religion and Globalization. London: Sage.

1998 The Religious System of Global Society: A Sociological Look at Contemporary Religion and Religions. Numen 45: 1-29.

Blier, Suzanne Preston

1995 African Vodun: Art, Psychology, and Power. Chicago: University of Chicago Press.

\section{Bochinger, Christoph}

1995 "New Age" und moderne Religion: Religionswissenschaftliche Analysen. Gütersloh: Chr. Kaiser. [2.ed.]

\section{Brown, Karen McCarthy}

1991 Mama Lola: A Vodou Priestess in Brooklyn. Berkeley: University of California Press.

\section{Bruce, Steve}

1996 Religion in the Modern World: From Cathedrals to Cults. Oxford: Oxford University Press.

Campbell, Joseph

1988 The Power of Myth. New York: Doubleday.

Carrasco, David

1995 Jaguar Christians in the Contact Zone. In: Anthony M. StevensArroyo and Andres I. Perez y Mena (eds.), Enigmatic Powers: Syncretism with African and Indigenous Peoples' Religions among Latinos; pp. 69-79. New York: Bildner Center for Western Hemisphere Studies. (Bildner Center Series on Religion, 3; PARAL Studies, 3) 
1996 Jaguar Christians in the Contact Zone. [unpubl. paper, Western Maryland College, Westminster]

\section{Clifford, James}

1997 Routes: Travel and Translation in the Late Twentieth Century. Cambridge: Harvard University Press.

\section{Cohen, Robin}

1997 Global Diasporas: An Introduction. London: UCL Press.

Coote, Jeremy, and Anthony Shelton (ed.)

1992 Anthropology, Art, and Aesthetics. Oxford: Clarendon Press.

Davies, Ioan

1995 Cultural Studies and Beyond: Fragments of Empire London: Routledge.

\section{Dillenberger, Jane}

1965 Style and Content in Christian Art. New York: Crossroads.

\section{Eck, Diana L.}

1996 Neighboring Faiths: How Will Americans Cope with Increasing Religious Diversity? Harvard Magazine (September/October): 38-44.

1997 On Common Ground: World Religions in America. New York: Columbia University Press. [optical disk]

\section{Eliade, Mircea}

1961 Images and Symbols: Studies in Symbolism. London: Harvill.

Gill, Sam. D.

1982 Beyond "The Primitive": The Religions of Nonliterate Peoples. Englewood Cliffs: Prentice-Hall.

Gruchy, J. W. de, and S. Martin (eds.)

1995 Religion and the Reconstruction of Civil Society. Pretoria: University of South Africa.

\section{Hackett, Rosalind I. J.}

1996a Art and Religion in Africa. London: Cassell.

1996b "African Art as Interface of Religious and Social Change." In: Iva Dolezalova, Bretislav Horyna and Dalibor Papousek (eds.), Religions in Contact; pp. 97-110. Brno: Czech Society for the Study of Religion.

1998a Charismatic/Pentecostal Appropriation of Media Technologies in Ghana and Nigeria. Journal of Religion in Africa 28: 258-77.

1998b Art as Neglected 'Text' for the Study of Gender and Religion in Africa. Religion 28: 363-370.

1993 The Symbolics of Power Discourse among Contemporary Religious Groups in West Africa. In: L. Martin (ed.), Religious Transformations and Socio-Political Change; pp. 381-409. Berlin: Mouton de Gruyter.

Hanegraaff, Wouter J.

1996 New Age Religion and Western Culture: Esotericism in the Mirror of Secular Thought. Albany: State University of New York Press. (Studies in the History of Religions 72)

Hall, Stuart, and Paul du Gay (eds.)

1996 Questions of Cultural Identity. London: Sage. 


\section{Hannerz, Ulf}

1996 Transnational Connections: Culture, People, Places. London: Routledge.

Heelas, Paul

1996 The New Age Movement: The Celebration of the Self and the Sacralization of Modernity. Oxford: Blackwell.

Hinga, Teresia $M$.

1996 The Academic Study of Religion in Kenya: Historical Roots, Contemporary Issues and Future Prospects. In: Jan Platvoet, James Cox and Jacob Olupona (eds.), The Study of Religions in Africa: Past, Present and Prospects; pp. 220-228. Cambridge: Roots and Branches. (Religions of Africa, 1)

Hoover, Stewart M. and Knut Lundby (eds.)

1997 Rethinking Media, Religion, and Culture. Thousand Oaks: Sage.

Hopkins, Dwight N., and Sheila Greeve Davaney (eds.)

1996 Changing Conversations: Religious Reflection \& Cultural Analysis. New York: Routledge.

Hulsether, Mark

1997 Three Challenges for the Field of American Studies: Relating to Cultural Studies, Addressing Wider Publics, and Coming to Terms with Religions. American Studies 38.

\section{Jensen, Tim}

1998 The Scholar of Religion as a Cultural Critic: Perspectives from Denmark. Bulletin. Council of Societies for the Study of Religion 27: 4043.

Klasnja, Predrag

1995 Internet-based Spirituality: An Introduction. [unpubl. College Scholar's Project, University of Tennessee]

\section{Knott, Kim}

1994 Hinduism in Leeds. A Study of Religious Practice in the Indian Hindu Community and in Hindu-Related Groups. Leeds: Community Religious Project [1986]

\section{Krüger, J.S}

1995 Along Edges: Religion in South Africa: Bushman, Christian, Buddhist. Pretoria: University of South Africa. (Hiddingh-Currie, 5)

\section{Laeuchli, Samuel}

1980 Religion and Art in Conflict. Philadelphia: Fortress Press.

\section{Launay, Robert}

1997 Spirit Media: the Electronic Media and Islam among the Dyula of Northern Côte d'Ivoire. Africa 67: 441-53.

Lewis, James R., and J. Gordon Melton (eds.)

1992 Perspectives on the New Age. Albany: State University of New York Press.

\section{Marty, Martin}

1997 The One and the Many: America's Struggle for the Common Good. Cambridge: Harvard University Press. 


\section{Meyer, Birgit}

1992 "If You Are a Devil, You Are a Witch, and, If You Are a Witch, You Are a Devil". Journal of Religion in Africa 22: 98-132.

\section{Miles, Margaret}

1998 Image. In: Mark C. Taylor (ed.), Critical Issues for Religious Studies; pp. 160-172. Chicago: University of Chicago.

Moore, Albert C.

1995 Arts in the Religions of the Pacific: Symbols of Life. London: Pinter.

\section{Murdock, Graham}

1997 The Re-Enchantment of the World: Religion and the Transformation of Modernity. In: Stewart M. Hoover and Knut Lundby (eds.), Rethinking Media, Religion, and Culture; pp. 85-101. Thousand Oaks: Sage.

Napier, A. David

1986 Masks, Transformation, and Paradox. Berkeley: University of California Press.

\section{Nye, Malory}

1996 Hare Krishna and Santan Dharm in Britain: The Campaign for Bhaktivedanta Manor. Journal of Contemporary Religion 11: 37-56.

\section{O'Leary, Stephen D.}

1996 Cyberspace as Sacred Space: Communicating Religion on Computer Networks. Journal of the American Academy of Religion 64: 781-808.

\section{O'Leary, Stephen D. and Brenda Brasher}

1996 The Unknown God of the Internet: Religious Communication from the Ancient Agora to the Virtual Forum. In: Charles Ess (ed.), Philosophical Approaches to Computer-Mediated Communication. Albany: State University of New York Press.

\section{Olupona, Jacob $\mathbb{K}$.}

1996 The Study of Religions in Nigeria. In: Jan Platvoet, James Cox and Jacob Olupona (eds.), The Study of Religions in Africa: Past, Present and Prospects; pp. 185-210. Cambridge: Roots and Branches.

Olupona, Jacob K. (ed.)

1992 Religion and Peace in a Multi-Faith Nigeria. Ife.

\section{Pietz, William}

1985 The Problem of the Fetish 1. RES 9: 5-17.

1987 The Problem of the Fetish 2. RES 12: 23-45.

1988 The Problem of the Fetish 3a. RES 16: 105-123.

Pratt, Mary Louise

1992 Imperial Eyes: Travel Writing and Transculturation London: Routledge.

Prozesky, Martin H.

1992 Proposals for a Criteriology of Religion. Journal for the Study of Religion 5: 67-77.

1996 South Africa's Contribution to Religious Studies. In: Jan Platvoet, James Cox and Jacob Olupona (eds.), The Study of Religions in Africa: Past, Present and Prospects; 229-254. Cambridge: Roots and Branches. 
Raschke, Carl A., James A. Kirk, and Mark C. Taylor

1977 Religion and the Human Image. Englewood Cliffs: Prentice-Hall.

Robertson, Roland

1989 Globalization, Politics and Religion. In: James A. Beckford and Thomas Luckmann (eds.), The Changing Face of Religion; pp. 45-61. London: Sage.

\section{Rosaldo, Renato}

1989 Culture and Truth: The Remaking of Social Analysis. Boston: Beacon. Rydving, Håkan

1993 The End of Drum-Time: Religious Change among the Lule Saami, 1670s-1740s. Stockholm: Almqvist and Wiksell. (Historia Religionum, 12)

Schalk, Peter (ed.)

1998 Being Religious and Living Through the Eyes: Studies in Religious Iconography and Iconology. A Celebratory Publication in Honour of Professor Jan Bergman. Uppsala: Uppsala University. (Historia Religionum, 14)

Shaw, Rosalind

1990 'The Invention of 'African Traditional Religion.' Religion 20: 339-354.

Sillk, Mark

1995 Unsecular Media: Making News of Religion in America. Urbana: University of Illinois Press.

Smart, Ninian

1983 Worldviews: Crosscultural Explorations of Human Beliefs New York: Scribner's.

1987 The Importance of Diasporas. In: S. Shaked, D. Shulman and G. G. Stroumsa (eds.), Gilgul : Essays on Transformation, Revolution, and Permanence in the History of Religions, Dedicated to R. J. Zwi Werblowsky; pp. 288-297. Leiden: E. J. Brill. (Studies in the History of Religions, 50)

1989 The World's Religions. Englewood Cliffs: Prentice-Hall.

1996 Dimensions of the Sacred: An Anatomy of the World's Beliefs. San Francisco: Harper and Row.

Stewart, Charles, and Rosalind Shaw (eds.)

1994 Syncretism/Anti-Syncretism: The Politics of Religious Synthesis. London: Routledge.

Taylor, Mark C.

1992 Disfiguring: Art, Architecture, Religion. Chicago: University of Chicago Press.

Taylor, Mark C. (ed.)

1998 Critical terms for Religious Studies Chicago: University of Chicago Press.

Thompson, John B.

1990 Ideology and Modern Culture: Critical Theory in the Era of Mass Communication. Cambridge: Polity Press. 


\section{Vertovec, Steven}

1993 Annotated Bibliography of Academic Publications Regarding Islam and Muslims in the United Kingdom, 1985-1992. Coventry: Centre for Research in Ethnic Relations, University of Warwick. (Bibliographies in Ethnic Relations, 11)

Werbner, Pnina, and Tariq Modood (eds.)

1997 Debating Cultural Hybridity: Multicultural Identities and the Politics of Anti-Racism. London: Zed Press. 